\title{
The Impact of Social Media Marketing on Consumer - Moderating Role of Gender and Income
}

\author{
Dr. Shahin Akbarov \\ Azerbaijan State University of Economics (UNEC), Azerbaijan
}

\begin{abstract}
Purpose: The purpose of this study is to investigate the impact of social media marketing activities on consumer behavior (i.e. value consciousness, brand consciousness, and brand loyalty) in the light of the moderation effect of gender and income.

Methodology: The questionnaire method was used for data collection. 261 questionnaire was gained through convenience and snowball sampling. Data were analyzed with SPSS-24 and AMOS-23. Explanatory factor analysis was first done with SPSS. To test the moderation effects multigroup moderation analysis was performed in AMOS.
\end{abstract}

Findings: SMM (perceived social media marketing activities) impacts brand loyalty (for male, female, and lower-income sample), value consciousness (for male, higher income, and lower-income sample), and brand consciousness (for male, higher income, and lower-income sample). The effect of gender as a moderator is not statistically significant. The effect of income as a moderator is significant in only two paths.

Originality/Importance: At a time when social media usage increases and brand loyalty declines, it is important to investigate the impact of social media marketing activities on consumer behavior. The present study underlines the value of replication studies in a cross-cultural context. Besides, the moderation effect of gender and income were tested.

Keywords: Social Media Marketing, Brand Consciousness, Value Consciousness, Brand Loyalty, Azerbaijan, Emerging Economies.

Paper type Research paper

\section{INTRODUCTION}

Recent improvements in social media activities related to peer and friend recommendations, usergenerated content, and product reviews and feedbacks play an increasingly central role in consumer engagement and consumer involvement (Rohm et al., 2013). Brands are on social networking sites to participate, create brand awareness, and benefit from word-of-mouth communication (Kujur and Singh, 2016). With companies creating their own corporate pages on social networking sites, social networking sites have experienced an extraordinary expansion over the last years and have become an important channel for communication and marketing (Herrero et al, 2017).

Social Media is a group of internet-based applications built on the ideological and technological foundations of Web 2.0, allowing the creation and exchange of user-generated content (Kaplan and Haenlein, 2010), aimed at facilitating the exchange of content, interactions and collaborations (Kim 
and Ko, 2012). It covers a wide range of online and word-of-mouth forums, including blogs, weblogs, moblogs, microblogging, social networking sites, discussion boards and chat rooms, wikis, podcasts, social bookmarking, consumer-to-consumer e-mail, content communities, virtual worlds, consumer product or service rating sites (Green, 2016; Kim and Ko, 2012; Vernuccio, 2014). Tsimonis and Dimitriadis (2014) point out that there is no definitive typology for different types of social media. The common feature is that social media allows individuals and entrepreneurs to take part in social interactions in a way and scale that was not previously possible (Tsimonis and Dimitriadis, 2014).

International studies show that high economic growth, and consequently the increase in per capita income, causes consumption patterns to shift from compulsory consumption to discretionary consumption. Consumers begin to try brands and become brand conscious (Sharda and Bhat, 2018). The development of retail is closely linked to the development of brand awareness (Mukherjee et al., 2012). The development of brand awareness for the Azerbaijani consumer is evident after the 2000s with the flow of oil revenues to the country, the development of retail and the widespread use of the Internet. According to the data prepared by "We Are Social" 7.64 million people out of 9.92 million in Azerbaijan are internet users (January 2017 report). This is 28\% higher than in January 2016. According to the company's report, 2.1 million of internet users are active social media subscribers. This is 31\% higher than in January 2016. With 2.1 million users, Facebook is the most popular social media channel. $38 \%$ of users enter Facebook every day. In general, $69 \%$ of social media users are male and $31 \%$ are female.

Social media has been increasingly used as an effective marketing tool in recent years. This trend is also manifested in Azerbaijan. Social media has become a new medium in communicating with consumers in an environment where the influence of traditional media is weakening and a large number of firms want to deliver messages to consumers. Social media, on the one hand, enables consumers to obtain information and to make comparisons between alternatives, on the other hand, creates an environment for sharing information and for recognizing brands. Both traditional and digital media expose consumers to messages from different brands, thus reducing loyalty. This situation raises the question of how marketing activities in social media affect consumers.

Considering the increasing importance of social media in the marketing activities of enterprises, the present study will address the effects of social media marketing activities on brand consciousness, value consciousness, and brand loyalty. Ismail (2017) in his study in Malaysia, investigated the relationships in question. The replications of studies are important for generalizations in marketing (Evanschitzky et al., 2008). However, this study differs from Ismail’s (2017) study in several ways. First, the present study was conducted in a different country (so in a different context). Second, the moderation effect of gender and income have been considered. Third, in this study non-students were also included in the sample.

In this study, the literature in the related field is first reviewed. Second, the methods and measures of the study are detailed. Then the findings of the survey research were presented. Finally, the main results of the analysis are discussed, the main conclusions and limitations of this study are summarized, and suggestions for further research are proposed.

\section{LITERATURE REVIEW}

\section{Social Media Marketing}

Chikandiwa et al. (2013) describe social media marketing, as a system that allows marketers to engage, collaborate, interact, and harness collective intelligence crowdsourcing for marketing purposes. It uses social media technologies, channels, and software to create, communicate, deliver, and exchange offerings that have value for an organization's stakeholders (Yadav and Rahman, 2018). Broad access to social media, low cost, and high communication efficiency make it attractive for many companies to participate in such areas (Kaplan and Haenlein, 2010). Interacting with customers, establishing/improving relationships with customers, collection of customer feedback, brand awareness, customer participation, creation of communities, promoting products, increasing sales, and more targeted customers, recognition of new business opportunities are the main outputs that 
companies expect from social media (Tsimonis and Dimitriadis, 2014; Arrigo, 2018; Kusumasondjaja, 2018).

Studies evaluating the social media (in particular social networking sites) in terms of consumers and brands, include the reasons for the consumer's participation in social networking sites (Kananukul et al., 2015; Gunawan and Huarng, 2015; Campbell et al., 2014), the activities of consumers in social networking sites (Dessart et al., 2015), the effects of social networking sites on brand and branding (Shang et al., 2016; Peruta et al., 2013; Zheng et al., 2015; Ananda et al., 2019), and the effects of activities of firms in social networking sites on consumers (Park and Kim, 2014; Shang et al., 2016; Vendemia, 2017).

Companies actively use social media for advertising and marketing. Through social media, it is possible to realize integrated marketing activities with less effort and less cost than ever before (Kim and Ko, 2012). Social media marketing is about social participation resulting in earned media rather than paid media. Social media marketing is also distinguished by the presence of social communication (ie, created by the community) in spite of commercial (ie, firm-based, promotional) communication in online social communities (Campbell et al., 2014). Social media-based brand communities offer brand owners the opportunity to develop brand trust, brand loyalty and community sentiment among members (Laroche et al., 2012).

The rise in the use of social media and the emergence of social search plays a central role in consumer-brand interaction. Companies and brands should take into account the impact of social media on consumers and better understand the extent to which social media should and must play a role in consumer-brand interaction (Yazdanparast et al., 2016). Various authors say that social media offers a simple and inexpensive way to analyze consumer conversations and exchanges with brands. Interacting with each other, consumers share their experiences, perceptions, and expectations about brands online (Manara and Roquilly, 2011). Members can freely join their favorite brand communities on these sites and take their place in the online brand community through ongoing communication processes (eg. making positive comments about images and videos related to the brand or company, participation in content creation, social sharing, etc.) (Tsimonis and Dimitriadis, 2014).

Studies show that consumers tend to enter social networking sites because of perceived practical, social, and entertainment benefits (Kananukul et al., 2015; Enginkaya and Yilmaz, 2014, Rohm et al., 2013). Practical benefits arise from information sharing (in other words, customer feedback and useful information generated from questions) while interacting with a brand's profile on a social networking site. Second, the entertainment benefit is derived from relaxation and fun. Brand entertainment includes contests, sweepstakes, interactive games, word play and events (Bento et al., 2018). Third, social benefits are achieved through social development. If consumers want to feel their activity or to be recognized in the community, they can engage in discussions with other users, give/receive help, and thus achieve social development.

By integrating consumers into their social media sites, marketers can ensure synergistic effects on attitudes by strengthening interpersonal ties and interactions, and consequently, increase behavioral outcomes such as brand loyalty, purchase intention and electronic word-of-mouth (Martín-Consuegra et al., 2019). According to Yazdanparast et al. (2016), marketing activities of the brand in social media will create a positive attitude towards the brand and as a result, will create customer-based brand equity. The behaviors of brands regarding social media marketing will have a positive effect on the perceived quality, perceived value of the brand, perceived uniqueness and the desire to pay premium price (Yazdanparast et al., 2016). Ismail (2017), in his research in Malaysia, has found a positive impact of perceived social media marketing activities on brand loyalty, brand consciousness and value consciousness. Hutter et al. (2013) stated that loyalty to the brand page would have a positive impact on brand awareness.

In their research in Thailand, Kananukul et al. (2015) found that users who rely on social networking sites will trust to the brand. It is stated that the users of the social networking sites trusting the brand will be loyal to the brand and this will be reflected in the purchasing frequency and sales volume 
consequently (Kananukul et al., 2015). Consumer brand engagement generates positive attitudes towards the brand and it may make consumers feel more loyal through interactive brand experiences beyond purchase and an enduring psychological connection (Fernandes and Moreira, 2019). Park and Kim (2014) found that the relationship quality of the brand in social networks will have a positive effect on brand relationship quality and this will affect the consumers' willingness to pay more (price premium). According to Zheng et al., (2015), the perceived benefit will be positively related to participation in online brand communities on social networking sites. Participation of users in the online brand community on social networking sites will positively affect brand loyalty (Zheng et al., 2015).

\section{Brand Loyalty}

Brand loyalty is the commitment to buy again or patronize a preferred product or service consistently in the future, thereby causing repetitive same-brand or same brand-set purchasing, despite situational influences and marketing efforts having the potential to cause switching behavior (Oliver, 1997). It refers to the tendency to be loyal to a focal brand, which is demonstrated by the intention to buy the brand as a primary choice (Yoo and Donthu, 2001). Loyal customers are less likely to switch to a competitor solely because of price and they are willing to pay more for that brand and respond more favorably to a brand than non-loyal or switching consumers (Liu et al., 2017). Brand-loyal consumers also make more frequent purchases than comparable non-loyal customers (Tong and Hawley, 2009).

Based on the literature review of social media marketing and brand loyalty, the following hypothesis may be proposed:

H1. Perceived social media marketing activities has a positive and significant impact on brand loyalty

\section{Value Consciousness}

Value is the trade-off between the perceived cost and perceived benefit and is generally a relative (ie, personal and situational) concept (Kleijnena et al., 2007). By referring to Zeithaml (1988), Rubio, Villaseñor, and Oubiña (2014) point out that "perceived value is the ratio of the perceived quality of a product over the price paid for this product". Perceived value for money spent considers the product's quality, not in absolute terms but relative to the price of a specific brand (Rubio et al., 2014). Value consciousness can be defined as the concern of paying a low price for certain quality restrictions. The definition recognizes that a certain quality can be beyond the needs of some consumers and defines the concept of value as a quality/price ratio that has a quality constraint (Lichtenstein et al., 1990). Lichtenstein et al., (1990), found value consciousness to be related to involvement, product knowledge, and price knowledge (Pillai and Kumar, 2012).

According to Delgado-Ballester et al. (2011), value-conscious consumers tend to use a systematic strategy to process information to achieve more delicate decisions. Value consciousness is related to ongoing involvement; this increases the motivation for systematic information processing (Pillai and Kumar, 2012). Through this process, an individual judges by carefully examining and comparing the arguments for a course of action (Chaiken, 1980). That activity would include taking account of unitpricing information, reading product labels, comparing intrinsic attributes between brands, and making trial purchases (Delgado-Ballester et al., 2014). As trust levels for decisions increase, the risk associated with purchasing decisions decreases. Non-value conscious consumers, in contrast, are not sufficiently motivated to process information in such a detailed way (Rubio et al., 2014).

Value-conscious consumers are looking for products with higher price/quality compliance. Given the dynamics of the market, these consumers need to remain less loyal to certain brands (Ferreira and Coelho, 2015). Consumers with this decision-making style are conscious about sales and discounts, aiming to achieve the best value for their money and possibly make shopping by comparison (Kang et al., 2014). Previous studies show that value consciousness has a negative impact on brand loyalty (Ferreira and Coelho, 2015).

Research has shown that value-conscious consumers will introduce new brands and products to others and demand information from other people about the product. Dennis et al. (2010) found that 
for value-conscious consumers, price comparison and discounts are the advantages of social shopping websites. Customers can generate information and share opinions about a firm's products and services using social media (Arrigo, 2018). As social media has the ability to enhance users' ability to evaluate products (Algharabat, 2017), it is possible to say that value-conscious consumers can ask for opinions from social networking sites to ensure that they achieve the best value for the money they pay (Kang et al., 2014). Kang et al. (2014) found that price/value consciousness is positively related to looking for opinions in social networking sites and using social networking sites to show online social shopping behaviors.

Based on the literature review of value consciousness and social media marketing, the following hypotheses may be proposed:

H2. Perceived social media marketing activities has a positive and significant impact on value consciousness

H3. Value consciousness will negatively affect brand loyalty

\section{Brand Consciousness}

Brand consciousness means mental orientation to choose a product with a well-known and highly advertised brand. Consumers with strong brand consciousness tend to buy branded products that are well-known, expensive and heavily marketed (Ye et al., 2015). According to Liao and Wang (2009), brand-conscious consumers use brands to express fashion consciousness, express personality characteristics and reduce risk in purchasing decisions (Giovannini et al., 015; Soh et al., 2017). Brand conscious consumers have a strong desire to show their success. They want to see more attention from others. These customers tend to believe that higher-priced products have a higher quality level (Soh et al., 2017) and they buy and use branded luxury fashion products (Ngai and Cho, 2012) because of that branded luxury products will show their wealth and prestigious (Bian and Moutinho, 2011), high social class status (Chiu and Leng, 2016).

The desire to express self is one of the main motivations to acquire a branded product. Indeed, consuming branded products contributes to the construction of consumer self-concept (Solomon, 1983). As the level of sensitivity of consumers to normative interpersonal influences increases, brand consciousness also increases. In their study on Mexican consumers, Lee et al. (2008) determined that the normative influence (the need to create an image within the framework of others' thoughts through the acquisition and use of products and brands; the desire to meet the expectations of others in purchasing decisions) has a positive effect on brand consciousness. When the quality of a product is very difficult to assess, the structure of brand consciousness can be based on the consumers belief that a higher-priced brand symbolizes high-quality (Keller, 2013). Luxury brands are generally higher priced and luxury brand ownership is the key factor in developing the self-concept that is necessary for many interpersonal relationships so that one can attract the attention of others (Sirgy, 1982; Yim et al., 2014).

Doing online social shopping using social networking sites provides opinions and information from others about a brand's image and reputation. Kang et al. (2014) found that brand consciousness is positively related to searching for opinions on social networking sites and showing online social shopping behaviors using social networking sites. In their research on Chinese consumers, Ye et al. (2012) found that brand consciousness has a positive effect on brand loyalty and willingness to pay a price premium. Based on a literature review of brand consciousness and social media marketing, the following hypotheses may be proposed:

H4. Perceived social media marketing activities has a positive and significant impact on brand consciousness

H5. Brand consciousness will positively affect brand loyalty

\section{The Effect of Demographic Variables as a Moderator}

Moderator variables are widely used in marketing literature and scholars emphasize their importance for predicting consumer behavior (Walsh et al., 2008). Demographic variables, especially gender and 
income are extensively used as moderators (Jain et al., 2015; Kim, 2016; Lin et al, 2017; Kalinić et al., 2019; Lin and Wang, 2020). Demographic variables an important role as moderators of the relationship between psychological constructs (Henrique and Augusto de Matos, 2015). There is a gap in the literature regarding the moderation effect of income and gender on the relationships among the variables of the current study.

The effect of gender as a moderator

Gender has been extensively used as a moderator variable in marketing studies, especially when analyzing consumer behavior (Hur et al., 2014; Gilal et al., 2018; Osei-Frimpong, 2019). Research shows that males and females often process and evaluate information differently (Bhaduri and HaBrookshire, 2015) and they use different informational clues to understand the stimuli they receive (Pérez and del Bosque, 2015). Men rely on their self-generated information, but women tend to find associations between their existing self-generated information and new information (Bhaduri and HaBrookshire, 2015). In contrast to the analytical and logical nature of men, women are more subjective and intuitive. While men tend to be more selective when evaluating the information, women attempting to assimilate all available information (Pérez and del Bosque, 2015). Research shows that women spend more time evaluating a product than men, and have higher public self-consciousness (Walsh et al., 2017).

According to the American Customer Satisfaction Survey Index, female customers show higher levels of customer satisfaction than males (Ma et al., 2014). Rambocas et al. (2018) found that satisfied women are more inclined to repeat purchase behavior than men. Men are more willing to try new suppliers. Tolbert et al. (2014) found that females are likely to seek information at traditional retailers even though when a similar offering is available online. However, males evaluate online offers better than that store offers.

The differences between males and females have been observed in online communication, social media behavior of consumers and usage behaviors (Rahman et al., 2018). Compared to males, females are more socially focused, more aware of others' feelings and more likely to maintain interpersonal relationships with others ( $\mathrm{Li}$ and Chang, 2016). Women experience a greater sense of community. Men, on the other hand, exhibit greater independence (Memery et al., 2015). Females have more communal concerns and a higher need for affiliation and fostering of harmonious relationships with others (Ma et al., 2014). Osei-Frimpong (2019) found that there is a difference between males and females in their participation in social brand engagement behaviors.

It is possible to propose the following hypothesis, by considering the differences between men and women regarding psychological and behavioral factors such as information sharing, selfconsciousness, information processing, loyalty, community sense:

H6. Gender moderates all relationships among variables in the research model.

\section{The effect of income as a moderator}

Another demographic variable that is extensively used as moderators in marketing literature is income (Glynn and Chen, 2009; Henrique and Augusto de Matos, 2015; Rahman et al., 2018). The previous studies suggest that income relates to consumer loyalty. Higher incomes give consumers more freedom when they are dissatisfied with a service provider. In contrast, low-income consumers probable avoid search costs and remain with a present firm, even if their satisfaction levels diminish (Walsh et al., 2008). Studies on online purchase behaviors propose that higher-income users perceive lower implicit risks in engaging online purchases. However, low income might discourage the user from online purchases, due to possible financial losses that might occur if their decision fails (Tiruwa et al., 2018). Considering the literature that supports the moderation and differential effect of income, especially regarding loyalty, the following hypothesis can be proposed:

H7. Income moderates all relationships among variables in the research model.

\section{RESEARCH MODEL}


As a result of the literature review, the model in Figure 1. has been adopted as a research model. Based on the claims that social media marketing activities will have an impact on brand consciousness and value consciousness, and that brand consciousness and value consciousness will have an impact on brand loyalty, it is possible to say that brand consciousness and value consciousness will mediate the effect of social media marketing activities on brand loyalty. Thus:

H8. Brand consciousness has a mediating effect between perceived social media marketing activities and brand loyalty

H9. Value consciousness has a mediating effect between perceived social media marketing activities and brand loyalty

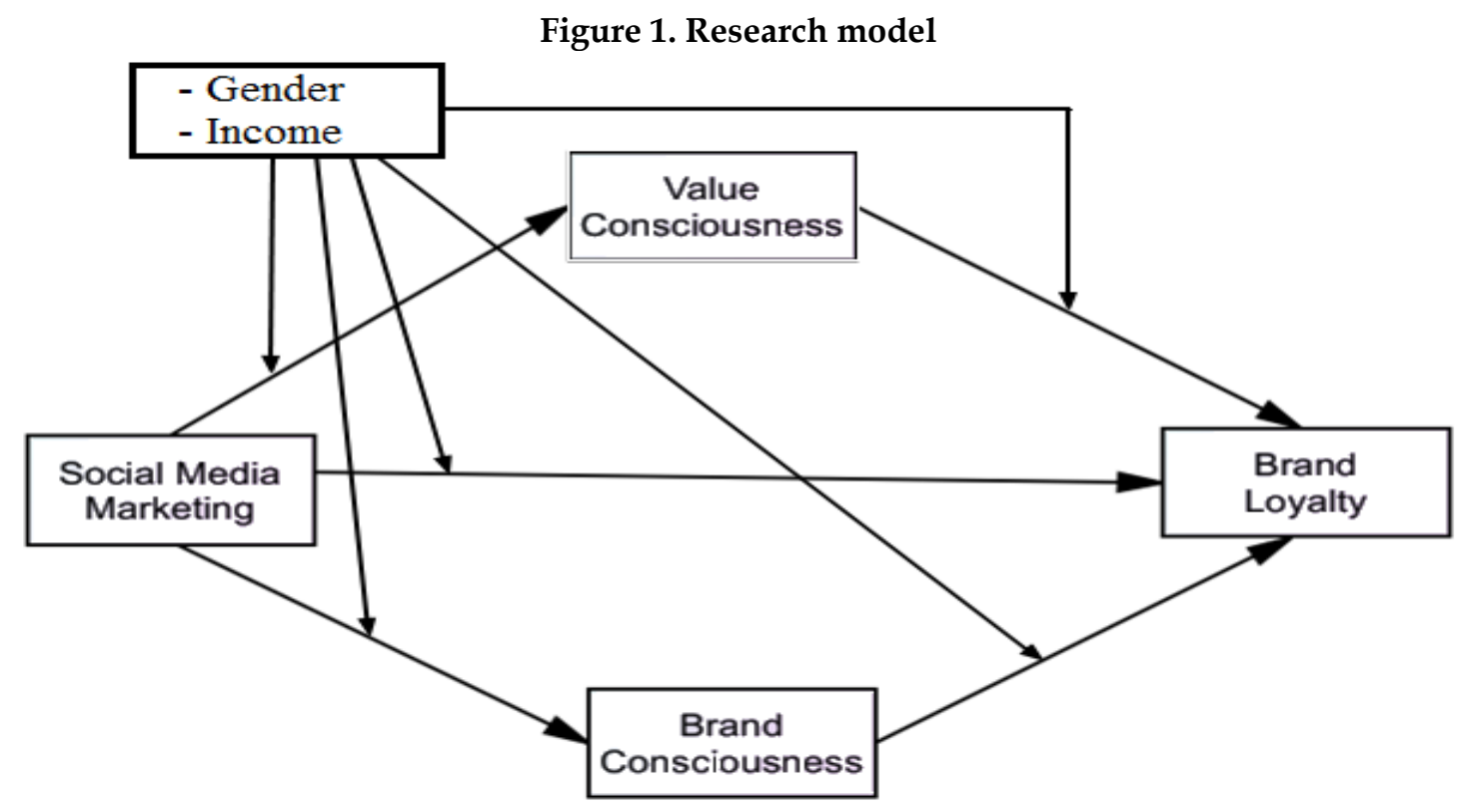

\section{Sample and procedure}

METHODOLOGY

The purpose of this study is to reveal the effects of social media marketing activities of the firms on brand consciousness, value consciousness and brand loyalty. As the universe of research, individuals over 18 years old who are residing in Baku and who have social media accounts have been selected. The convenience and snowball sampling methods were chosen as the sampling method. The questionnaire was developed in Google forms and distributed to the universe through personal Facebook addresses (also using snowball procedure) and through the Facebook page of one of the university research centers. The post on the Facebook page was promoted in order to reach more people. In addition, the method of hand-to-hand distribution was also used. It is thought that all of these will reduce the sampling bias and increase generalizability (Neuman, 2014:248-249). A total of 261 questionnaires were obtained.

\section{Measurement}

Scale items were adapted from previous studies (Ismail, 2017). Items were measured on a five-point Likert type scale where 1 representing "strongly disagree" and 5 "strongly agree". The data collection process took place in May 2017. The data were analyzed with SPSS 24 and AMOS 23.

\section{Analysis methods}

The scale items were subjected to factor analysis to determine the dimensions. Principal components factor analysis followed by a varimax rotation was performed.

The AMOS 23 was used to test the model and to test the relationships revealed in the framework of the model. Multi-group moderation analysis was conducted to determine the effect of gender and income as moderating variables. Two moderator variables (gender and income) were included in the 
analysis separately. The model was tested for each group that forms moderators (i.e. "male and female", and "low income and high income").

To investigate indirect effects, the bootstrapping procedure was implemented ( $\mathrm{n}=1000, \mathrm{BC}-\% 95)$ (Preacher and Hayes, 2004). To investigate individual indirect effects new estimands were defined in AMOS.

\section{ANALYSIS AND FINDINGS}

Demographic characteristics of the sample

Table 1 shows the demographic characteristics of the participants. 147 male and 114 female have participated in the questionnaire. 145 out of 261 were lower-income individuals. The majority of the participants are aged 18-25 (77\%). Facebook, Instagram and Youtube are the channels with the highest usage level among social media platforms

Table 1. Demographic characteristics and social media sites usage

\begin{tabular}{llcc}
\hline \multicolumn{1}{c}{ Variables } & \multicolumn{1}{c}{ Category } & Number & Percent \\
\hline \multirow{2}{*}{ Gender } & Male & 147 & 56,3 \\
& Female & 114 & 43,7 \\
\hline \multirow{2}{*}{ Age } & $18-25$ & 201 & 77,0 \\
& $26-45$ & 60 & 23,0 \\
\hline Monthly Income & $0-250$ AZN & 145 & 55,6 \\
$\mathbf{( 1 ~ A Z N ~ = ~ 0 . 5 9 ~ \$ ) ~}$ & $251+$ AZN & 116 & 44,4 \\
\hline \multirow{3}{*}{ Social media sites } & Facebook & 255 & $98 \%$ \\
& Instagram & 222 & $85 \%$ \\
& Youtube & 210 & $80 \%$ \\
& Linkedin & 98 & $38 \%$ \\
& Twitter & 85 & $33 \%$ \\
& Pinterest & 40 & $15 \%$ \\
& Vkontakte & 30 & $11 \%$ \\
& Ok.ru & 17 & $7 \%$ \\
\hline
\end{tabular}

Explanatory Factor Analysis, Reliability, Mean

Explanatory factor analysis results are given in Table 2.

Table 2. Factor Analysis Output

\begin{tabular}{|l|c|c|c|c|}
\hline \multicolumn{5}{|c|}{ KMO=0,799, Bartlett, df=120, Approx. Chi-Square=1326.434, $\mathbf{p}<0,001$, Cronbach's } \\
Alpha=0.815 & $\begin{array}{c}\text { Factor } \\
\text { Load }\end{array}$ & $\begin{array}{c}\text { Explained } \\
\text { variance }\end{array}$ & $\begin{array}{c}\text { Cronbach's } \\
\text { Alpha }\end{array}$ & Mean \\
\hline Factor & & $\mathbf{1 5 . 9 0 7}$ & $\mathbf{0 . 7 7 8}$ & $\mathbf{4 . 2 9}$ \\
\hline Value consciousness & .817 & & & 4,40 \\
\hline $\begin{array}{l}\text { When purchasing a product, I always try } \\
\text { to maximize the quality I get for the } \\
\text { money I spend }\end{array}$ & .807 & & & 4,25 \\
\hline $\begin{array}{l}\text { When shopping, I compare the prices of } \\
\text { different brands to be sure I get the best } \\
\text { value for the money }\end{array}$ & .751 & & & 4,33 \\
\hline $\begin{array}{l}\text { When I buy products, I like to be sure } \\
\text { that I am getting my money's worth }\end{array}$ & .651 & & & 4,19 \\
\hline $\begin{array}{l}\text { I am very concerned about low prices, } \\
\text { but I am equally concerned about }\end{array}$ & & & \\
\hline
\end{tabular}




\begin{tabular}{|c|c|c|c|c|}
\hline product quality & & & & \\
\hline Brand Loyalty & & 15.377 & 0.797 & 3.56 \\
\hline $\begin{array}{l}\text { I consider myself to be loyal to one brand } \\
\text { of product }\end{array}$ & .765 & & & 3,11 \\
\hline $\begin{array}{l}\text { I feel confident in a brand that I always } \\
\text { buy }\end{array}$ & .755 & & & 3,64 \\
\hline $\begin{array}{l}\text { I have certain types of brands that I } \\
\text { always buy }\end{array}$ & .728 & & & 3,86 \\
\hline $\begin{array}{l}\text { I would rather stick with a brand I } \\
\text { usually buy than try something I am not } \\
\text { very sure of }\end{array}$ & .720 & & & 3,63 \\
\hline Brand consciousness & & 15.368 & 0.757 & 3.28 \\
\hline $\begin{array}{l}\text { Brand names tell me something about } \\
\text { the } \\
\text { quality of the products }\end{array}$ & .837 & & & 3,46 \\
\hline $\begin{array}{l}\text { Sometimes I am willing to pay more } \\
\text { money for products because of its brand } \\
\text { name }\end{array}$ & .767 & & & 2,90 \\
\hline $\begin{array}{l}\text { I pay attention to the brand names of the } \\
\text { products I buy }\end{array}$ & .717 & & & 3,78 \\
\hline $\begin{array}{l}\text { Branded products that cost a lot of } \\
\text { money are good quality }\end{array}$ & .624 & & & 3,00 \\
\hline $\begin{array}{l}\text { Perceived social media marketing } \\
\text { activities }\end{array}$ & & 13.582 & 0.679 & 3.55 \\
\hline $\begin{array}{l}\text { Using social media to search for } \\
\text { information about the brand I am } \\
\text { considering buying is very trendy }\end{array}$ & .803 & & & 3,71 \\
\hline $\begin{array}{l}\text { I find interesting contents shown in } \\
\text { social media about the brand I am } \\
\text { considering to buy }\end{array}$ & .681 & & & 3,41 \\
\hline $\begin{array}{l}\text { It is easy to deliver my opinion about the } \\
\text { brand I am considering buying through } \\
\text { social media }\end{array}$ & .674 & & & 3,94 \\
\hline $\begin{array}{l}\text { I would like to pass along information on } \\
\text { the brand, product, or services from } \\
\text { social media to my friends }\end{array}$ & .624 & & & 3,13 \\
\hline Total Variance Explained & \multicolumn{4}{|c|}{60.234} \\
\hline
\end{tabular}

As a result of factor analysis, 4 factors (generated automatically by software) were determined: "Value consciousness", "brand loyalty", "Brand consciousness", and "Perceived social media marketing activities". The factor with the highest exploratory value was "Value Consciousness" (15.907). The factor with the highest reliability was "Brand Loyalty" (0.797). The factor with the highest mean score was "Value Consciousness" (4.29) and thus, it was found that the participants had higher value consciousness.

Path Analysis (Multigroup Moderation)- Moderating effect of gender

For investigating model fit, Relative Chi-Square Index (CMIN/DF), Goodness-Of-Fit Index (GFI), Comparative Fit Index (CFI), The Root Mean Square Error of Approximation (RMSEA) were considered. The results were as follows: $2.533 ; 0.990 ; 0.972$ and 0.077 respectively. These results are in accordance with the values accepted in the literature (Hair et al., 2014). 
Significant effect of perceived social media marketing activities on brand consciousness, value consciousness and brand loyalty was determined for the male sample. The impact of brand consciousness on brand loyalty was also statistically significant. The effect of value consciousness on brand loyalty was not significant for the male sample. For the female sample, the impact of perceived social media marketing activities on value consciousness and brand consciousness was not statistically significant. The impact of brand consciousness on brand loyalty, the effect of value consciousness on brand loyalty and the impact of perceived social media marketing activities on brand loyalty were significant for female sample. Standardized regression coefficients and their level of significance are given in Table 3.

Table 3. Standardized Regression Coefficients

\begin{tabular}{|c|c|c|c|c|c|c|c|c|}
\hline & & \multicolumn{3}{|c|}{ Male sample } & \multicolumn{3}{|c|}{ Female sample } & \multirow{2}{*}{ z-score } \\
\hline & & Estimate & S.E. & $\mathrm{P}$ & Estimate & S.E. & $\mathrm{P}$ & \\
\hline Brcon & $<---$ SMM & 241 & 090 & 003 & 161 & 112 & 082 & $-0,532$ \\
\hline Valcon & $<---\quad$ SMM & 299 & ,063 & $* * *$ & 111 & 100 & 235 & $-1,020$ \\
\hline Brloy & $<--$ Brcon & ,417 & ,069 & $* * *$ & ,305 & 074 & $* * *$ & $-1,059$ \\
\hline Brloy & <--- Valcon & 099 & ,099 & 184 & ,304 & ,083 & $* * *$ & 1,472 \\
\hline Brloy & $<---$ SMM & 173 & ,081 & ,024 & ,278 & ,090 & $* * *$ & 1,085 \\
\hline
\end{tabular}

SMM - Perceived Social Media Marketing Activities; Brcon - Brand Consciousness;

Valcon - Value Consciousness; Brloy - Brand Loyalty ${ }^{* * *} \mathrm{p}<0.001$

Z-scores demonstrate that there are no statistically significant differences in standardized regression coefficients in terms of gender groups.

As a result of the analysis, the indirect effect of perceived social media marketing activities on brand loyalty was found to be significant for male sample in $95 \%$ confidence interval $(p=0.010)$. The standardized regression coefficient, which shows the indirect effect of the perceived social media marketing activities on brand loyalty, is "0.130" (for the male sample). The standardized regression coefficient, which shows the total effect of perceived social media marketing activities on brand loyalty, is "0.303" $(0.173+0.130)$ (for male sample). For the female sample, the indirect effect was not significant $(\mathrm{p}=0.075)$.

Path Analysis (Multigroup Moderation) - Moderating effect od income

For investigating model fit Relative Chi-Square Index (CMIN/DF), Goodness-Of-Fit Index (GFI), Comparative Fit Index (CFI), The Root Mean Square Error of Approximation (RMSEA) were considered. The results were as follows: $2.527 ; 0.990 ; 0.972$ and 0.077 respectively.

The significant effect of perceived social media marketing activities on brand consciousness, value consciousness and brand loyalty was determined for a lower-income sample. The impact of brand consciousness on brand loyalty was also statistically significant (for lower-income samples). The impact of value consciousness on brand loyalty was not significant for the lower-income sample. For the higher-income sample, the impact of perceived social media marketing activities on value consciousness and brand consciousness was statistically significant. The impact of brand consciousness on brand loyalty and the impact of value consciousness on brand loyalty were also significant for higher-income samples. The impact of perceived social media marketing activities on brand loyalty was not statistically significant for a higher income sample. Standardized regression coefficients and their level of significance are given in Table 4.

Table 4. Standardized Regression Coefficients

\begin{tabular}{|c|c|c|c|c|c|c|c|c|}
\hline & & \multicolumn{3}{|c|}{ Lower-income sample } & \multicolumn{3}{|c|}{ Higher-income sample } & \multirow{2}{*}{ z-score } \\
\hline & & Estimate & S.E. & $\mathrm{P}$ & Estimate & S.E. & $\mathrm{P}$ & \\
\hline Brcon & $<---\quad$ SMM & 216 & ,094 & 008 & 221 & , 107 & 015 & 0,068 \\
\hline Valcor & $<--\quad$ SMM & 174 & 071 & 034 & 262 & ,089 & 004 & 0,945 \\
\hline
\end{tabular}




\begin{tabular}{|c|c|c|c|c|c|c|c|c|c|}
\hline & & & \multicolumn{3}{|c|}{ Lower-income sample } & \multicolumn{3}{|c|}{ Higher-income sample } & \multirow{2}{*}{ z-score } \\
\hline & & & Estimate & S.E. & $\mathrm{P}$ & Estimate & S.E. & $\mathrm{P}$ & \\
\hline Brloy & $<-$ & Brcon & ,352 & ,068 & $* * *$ & 394 & ,076 & $* * *$ & 0,437 \\
\hline Brloy & $<--$ & Valcon & ,102 & ,091 & 160 & 309 & ,092 & $* * *$ & $1,735^{*}$ \\
\hline Brloy & $<-$ & SMM & ,284 & , 080 & $* * *$ & ,078 & ,093 & 344 & $-1,789^{*}$ \\
\hline
\end{tabular}

*** $p<0.001 ;{ }^{*} \mathrm{p}<0.10$

Z-scores demonstrate two paths vary (Brloy <--- Valcon, Brloy <--- SMM) in terms of income groups. As a result of the analysis, the indirect effect of perceived social media marketing activities on brand loyalty was found to be significant for the lower-income sample (in $95 \%$ confidence interval, $\mathrm{p}=0.024$ ) as well as for the higher-income sample (in 95\% confidence interval, $\mathrm{p}=0.008$ ). The standardized regression coefficient, which shows the indirect effect of the perceived social media marketing activities on brand loyalty, was "0.094" (for lower-income sample). The standardized regression coefficient, which shows the total effect of perceived social media marketing activities on brand loyalty, is " 0.378 " $(0.284+0.094)$ (for lower-income sample). The standardized regression coefficient, which shows the indirect effect of the perceived social media marketing activities on brand loyalty, is "0.168" (for a higher-income sample).

\section{The significance of specific indirect effects}

The result indicates that both indirect effects ("SMM--->Brcon--->Brloy" and "SMM--->Valcon-->Brloy" ) are significant (Table 5).

Table 5. Specific Indirect Effects

\begin{tabular}{|l|c|c|}
\hline & Estimate & P \\
\hline Indirect effect 1: SMM--->Brcon--->Brloy &, 082 &, 004 \\
\hline Indirect effect 2: SMM--->Valcon--->Brloy &, 049 &, 002 \\
\hline
\end{tabular}

\section{Conclusions and Discussion}

The purpose of this study is to investigate the impact of social media marketing activities on consumer behavior (i.e. value consciousness, brand consciousness, and brand loyalty) in the light of the moderation effect of gender and income. Table 6 summarizes the results regarding the hypotheses.

Table 6. Results regarding hypotheses

\begin{tabular}{|l|l|l|l|l|}
\hline Hypotheses & Male & Female & Lower income & Higher income \\
\hline H1: SMM--->Brloy & Supported & Supported & Supported & Unsupported \\
\hline H2: SMM--->Valcon & Supported & Unsupported & Supported & Supported \\
\hline H3: Valcon---> Brloy & Unsupported & Unsupported & Unsupported & Unsupported \\
\hline H4: SMM--->Brcon & Supported & Unsupported & Supported & Supported \\
\hline H5: Brcon---> Brloy & Supported & Supported & Supported & Supported \\
\hline H6: Gender Moderation & \multicolumn{4}{|c|}{ Unsupported } \\
\hline H7: Income Moderation & \multicolumn{4}{|c|}{ Partly supported } \\
\hline H8: SMM--->Brcon--->Brloy & \multicolumn{4}{|c|}{ Supported } \\
\hline H9: SMM--->Valcon--->Brloy & \multicolumn{4}{|c|}{ Supported } \\
\hline
\end{tabular}

*Significant, but the positive impact

The direct effect of SMM on brand loyalty is significant for each sample (which in line with studies such as, Ismail, 2017; Yadav and Rahman, 2017; Algharabat, 2017; Ibrahim and Aljarah, 2018; Godey et al., 2016), except for the higher-income sample. For higher-income people, SMM will not create brand loyalty. This result may be explained with the proposition that higher incomes give consumers more freedom (Walsh et al., 2008), thus it is hard to make them loyal to the brand. 
SMM has a positive impact on value consciousness and brand consciousness for three samples. But for females, SMM doesn't impact value consciousness and brand consciousness.

In the case of all samples, brand consciousness affects brand loyalty. Regardless of the groups, the more the person is brand conscious, the more he/she is loyal to the brand. This finding is consistent with previous studies (Ye et al., 2012; Ismail, 2017).

It was expected that value consciousness will negatively affect brand loyalty. For male and lowerincome samples, there was not found any relationship between the two variables. But for the other two samples, contrary to previous research findings (Garretson et al., 2002; Ismail, 2017), even a positive impact of value consciousness on brand loyalty was found. This can be explained partially by the distinction between behavioral loyalty and attitudinal attachment, as stated by Keller (2013). According to Keller (2013), behavioral loyalty may be due to the fact that the brand is unrivaled in the market, the only brand that the consumer can buy, and other reasons. This situation may be valid for the Azerbaijani consumer. Because the country is new in the market economy, there are a few firms competing in the market.

The indirect effect of SMM on brand loyalty is significant for each sample, except for females. The mediation effect of brand consciousness and value consciousness on the relationship between SMM and brand loyalty is significant.

According to $\mathrm{z}$ scores, there are no statistically significant differences between males and females with regard to the paths of the model. However, from standardized regression coefficients, it seems that the effect of SMM on brand consciousness and value consciousness is significant only for males. At the same time, the direct impact (but not total) of SMM on brand loyalty is higher for females than for a male. Thus, SMM will not shape the consciousness of females, however, it will create loyalty. Literature (Ma et al., 2014; Rambocas et al., 2018) put forth that females are more inclined to be loyal. The finding of this study support this claim.

There are statistically significant differences between the lower-income sample and higher-income sample with regard to the relationship between SMM and value consciousness and between value consciousness and brand loyalty. As pointed out, for the lower-income sample there is no statistically significant relationship between value consciousness and brand loyalty, in contrast, for the higherincome sample this relationship is high. The direct effect of SMM on brand loyalty is significant only for the lower-income sample. The other paths are almost identical for both samples. For lower-income samples, SMM creates more brand-conscious consumers than value-conscious ones. In contrast, for a higher-income sample, SMM creates more value-conscious consumers than brand-conscious ones.

\section{Implications for theory and practice}

This study contributes to the theory in several ways. First, a subject that is up-to-date and less researched has been investigated. The impact of social media marketing on brand consciousness, value consciousness, and brand loyalty was determined. Secondly, the relationships mentioned above were compared in terms of gender and income groups. Although to test the moderation effect of demographic variables is widely used in literature, there is a gap regarding using them in the relationships that form the model of the current study. Third, this study includes the value of replication studies in cross-cultural contexts.

The study has some implications for practitioners (managers) also. As it is known that segmentation is one of the common practices that companies use. Especially gender and income basis segmentation is mostly preferred for its easily identifiable, accessible and measurable feature. In this sense, this study provides insights for firms to know the behavior of different segments (i.e. male vs female, lower-income people vs higher-income people) regarding the variables of this study. 
Whether businesses want to attract value-conscious consumers by emphasizing value or attract brand-conscious consumers by highlighting the brand and applying the premium price, they must pay careful attention to social media marketing activities. SMM activities create value-conscious and brand-conscious people in the male, lower-income, and higher-income segments. Social media marketing activities are also important for firms that target males, females, and lower-income people to create brand loyalty. Firms can reach this by making it easier for consumers to engage in social media, find useful content, and share their opinions with friends on social media. Firms can also increase brand loyalty by enhancing brand consciousness or value consciousness via social media marketing activities. The good news for firms is that even value-conscious consumers may be loyal if they are females and if they are higher-income people. It is an opportunity for firms that emphasizes value.

\section{Limitations and suggestions for future research}

One of the limitations of this research is regarding the sampling method. As the research used convenience sampling, it may raise the problem for the generalizability of results. The second limitation is the low number of samples. The unwillingness of people to respond to the questionnaire reduced responses.

For future research, the addition of attitudinal attachment into the model may have explanatory results in terms of theory. Besides, using age as a moderator variable will be in place. The third suggestion for future studies is to test the model in a developed country context.

\section{REFERENCES}

[1]. Algharabat R.S. (2017). "Linking social media marketing activities with brand love: The mediating role of self-expressive brands", Kybernetes, Vol. 46, No. 10, pp. 1801-1819. 10.1108/K-04-2017-0130

[2]. Ananda A.S., Hernández-García Á., Acquila-Natale E. and Lamberti L. (2019). What makes fashion consumers "click"? Generation of eWoM engagement in social media, Asia Pacific Journal of Marketing and Logistics, https:// doi.org/10.1108/APJML-03-2018-0115

[3]. Arrigo E. (2018). Social media marketing in luxury brands: A systematic literature review and implications for management research. Management Research Review, 41 (6), 657-679. https://doi.org/10.1108/MRR-04-2017-0134

[4]. Bento M., Martinez L.M. and Martinez L.F. (2018). Brand engagement and search for brands on social media: Comparing Generations X and Y in Portugal. Journal of Retailing and Consumer Services, 43, 234-241. https://doi.org/10.1016/j.jretconser.2018.04.003.

[5]. Bhaduri G. and Ha-Brookshire J.E. (2015), "Gender differences in information processing and transparency: cases of apparel brands' social responsibility claims", Journal of Product and Brand Management, 24/5, pp. 504-517. 10.1108/JPBM-08-2014-0683]

[6]. Bian Xuemei, Luiz Moutinho, (2011) "The role of brand image, product involvement, and knowledge in explaining consumer purchase behaviour of counterfeits: Direct and indirect effects", European Journal of Marketing, Vol. 45 Issue: 1/2, pp.191-216, https:// doi.org/10.1108/03090561111095658

[7]. Campbell, C., Ferraro, C., and Sands, S. (2014). Segmenting consumer reactions to social network marketing. European Journal of Marketing, 48 (3/4), 432-452. http:// dx.doi.org/10.1108/EJM-03-20120165

[8]. Chikandiwa S.T., Contogiannis E. and Jembere E. (2013). The adoption of social media marketing in South African banks. European Business Review, 25 (4), 365 - 381. http://dx.doi.org/10.1108/EBR-022013-0013

[9]. Delgado-Ballester, E., Hernandez-Espallardo, M., and Rodriguez-Orejuela, A. (2014). Store image influences in consumers' perceptions of store brands: the moderating role of value consciousness. European Journal of Marketing, 48 (9/10), 1850-1869. https:// doi.org/10.1108/EJM-02-2012-0087.

[10]. Dennis, C., Morgan, A., Wright, L.T. and Jayawardhena, C. (2010). The influences of social e-shopping in enhancing young women's online shopping behavior. Journal of Customer Behaviour, 9 (2), 151-174.

[11]. Dessart, L., Veloutsou, C., and Morgan-Thomas, A. (2015). Consumer engagement in online brand communities: a social media perspective. Journal of Product and Brand Management, 24 (1), 28-42. http://dx.doi.org/10.1108/JPBM-06-2014-0635.

[12]. Enginkaya E. and Yilmaz H. (2014). What drives consumers to interact with brands through social media? A motivation scale development study. Procedia - Social and Behavioral Sciences, 148, 219-226. http://dx.doi.org/10.1016/j.sbspro.2014.07.037 
[13]. Evanschitzky H., v. Wangenheim F., Woisetschläger D. and Blut M. (2008), "Consumer ethnocentrism in the German market", International Marketing Review, Vol. 25 No. 1, pp.7-32, https://doi.org/10.1108/02651330810851863

[14]. Fernandes T., Moreira M. (2019). Consumer brand engagement, satisfaction and brand loyalty: a comparative study between functional and emotional brand relationships. Journal of Product and Brand Management, https://doi.org/10.1108/JPBM-08-2017-1545

[15]. Ferreira, A. G., and Coelho, J.F. (2015). Product involvement, price perceptions, and brand loyalty. Journal of Product and Brand Management, 24 (4), 349-364. https://doi.org/10.1108/JPBM-06-20140623.

[16]. Garretson, J.A., Fisher, D. and Burton, S. (2002). Antecedents of private label attitude and national brand promotion attitude: similarities and differences. Journal of Retailing, 78 (2), 91-100.

[17]. Gilal F. G., Zhang J., Gilal N.G. and Gilal R.G. (2018), "Linking motivational regulation to brand passion in a moderated model of customer gender and age: an organismic integration theory perspective", Rev Manag Sci, pp 1-27. https://doi.org/10.1007/s11846-018-0287-y

[18]. Giovannini, S., Xu, Y., and Thomas, J. (2015). Luxury fashion consumption and Generation Y consumers: Self, brand consciousness, and consumption motivations. Journal of Fashion Marketing and Management, 19 (1), 22-40. https:// doi.org/10.1108/JFMM-08-2013-0096.

[19]. Glynn M.S. and Chen S. (2009), "Consumer-factors moderating private label brand success: further empirical results", International Journal of Retail and Distribution Management, Vol. 37, No. 11, pp. 896-914. 10.1108/09590550910999343.

[20]. Godey B., Manthiou A., Pederzoli D., Rokka J., Aiello G., Donvito R. and Singh R. (2016). "Social media marketing efforts of luxury brands: Influence on brand equity and consumer behavior", Journal of Business Research, Vol. 69, pp. 5833-5841. http://dx.doi.org/10.1016/j.jbusres.2016.04.181

[21]. Green, M.R. (2016). The impact of social networks in the development of a personal sports brand. Sport, Business and Management: An International Journal, 6 (3), $274 \quad-294$. http://dx.doi.org/10.1108/SBM-09-2015-0032.

[22]. Grinsven, B., and Das, E. (2015). Processing different degrees of logo change: When higher levels of brand consciousness decrease openness to substantial logo changes. European Journal of Marketing, 49 (11/12), 1710-1727. https://doi.org/10.1108/EJM-02-2014-0127.

[23]. Gunawan, D. D., and Huarng, K. ( 2015). Viral effects of social network and media on consumers' purchase intention. Journal of Business Research, 68, 2237-2241. http://dx.doi.org/10.1016/j.jbusres.2015.06.004

[24]. Hair J.F., Black W.C., Babin B.J. and Anderson R.E. (2014), Multivariate Data Analysis (Seventh Edition). Pearson Education, United States, USA.

[25]. Henrique J.L. and Augusto de Matos C. (2015), "The influence of personal values and demographic variables on customer loyalty in the banking industry", International Journal of Bank Marketing, Vol. 33, No. 4, pp. 571-587. https:// doi.org/10.1108/IJBM-06-2014-0082

[26]. Herrero, A., San Martín, H., and Salmones, M. (2017). Explaining the adoption of social networks sites for sharing user-generated content: A revision of the UTAUT2. Computers in Human Behavior, 71, 209-217. http://dx.doi.org/10.1016/j.chb.2017.02.007.

[27]. Hur W.M., Kim H. and Kim W.M. (2014), "The Moderating Roles of Gender and Age in Tablet Computer Adoption", Cyberpsychology, Behavior, And Social Networking, Vol. 17, No. 1, pp. 33-39. 10.1089 /cyber.2012.0435

[28]. Hutter, K., Hautz, J., Dennhardt, S., and Füller, J. (2013). The impact of user interactions in social media on brand awareness and purchase intention: the case of MINI on Facebook, Journal of Product and Brand Management, 22 (5/6), 342 - 351. http:/ / dx.doi.org/10.1108/JPBM-05-2013-0299.

[29]. Ibrahim B. and Aljarah A. (2018). "Dataset of relationships among social media marketing activities, brand loyalty, revisit intention. Evidence from the hospitality industry in Northern Cyprus", Data in Brief, Vol. 21, pp. 1823-1828. https://doi.org/10.1016/j.dib.2018.11.024

[30]. Ismail Ahmed Rageh, (2017) "The influence of perceived social media marketing activities on brand loyalty: The mediation effect of brand and value consciousness", Asia Pacific Journal of Marketing and Logistics, Vol. 29 Issue: 1, pp.129-144, https://doi.org/10.1108/APJML-10-2015-0154

[31]. Jain V., Roy S. and Ranchhod A. (2015), "Conceptualizing luxury buying behavior: the Indian perspective", Journal of Product and Brand Management, 24/3, pp. 211-228. 10.1108/JPBM-07-20140655

[32]. Kananukul, C., Jung, S., and Watchravesringkan K. (2015). Building customer equity through trust in social networking sites A perspective from Thai consumers. Journal of Research in Interactive Marketing, 9 (2), 148 - 166. http:/ / dx.doi.org/10.1108/JRIM-03-2014-0019. 
[33]. Kang, J.M., Kim, K.P.J, andWu, J. (2014). Consumer style inventory and intent to social shop online for apparel using social networking sites. Journal of Fashion Marketing and Management, 18 (3), 301-320. https://doi.org/10.1108/JFMM-09-2012-0057.

[34]. Kaplan, A. M. and Haenlein, M. (2010). Users of the world, unite! The challenges and opportunities of social media. Business Horizons, 53 (1), 59-68.

[35]. Keller, K.L. (2013). Strategic Brand Management: Building, measuring and managing brand equity (4th ed.) Global Edition, Pearson Education Limited.

[36]. Kim J. (2016). "An extended technology acceptance model in behavioral intention toward hotel tablet apps with moderating effects of gender and age", International Journal of Contemporary Hospitality Management, Vol. 28, No. 8, pp. 1535-1553. 10.1108/IJCHM-06-2015-0289

[37]. Kim, A.J. and Ko E. (2012). Do social media marketing activities enhance customer equity? An empirical study of luxury fashion brand. Journal of Business Research, 65, 1480-1486. 10.1016/j.jbusres.2011.10.014

[38]. Kleijnena, M., de Ruyter, K., and Wetzels, M. (2007). An assessment of value creation in mobile service delivery and the moderating role of time consciousness. Journal of Retailing, 83 (1), 33-46. doi:10.1016/j.jretai.2006.10.004.

[39]. Kujur, F, Singh, F (2016). Social Networking Sites as a Multimedia Tool for Brand Popularity - An Exploratory Study, Indian Journal of Science and Technology, Vol. 9 No 45, pp $1-7$

[40]. Kusumasondjaja S. (2018). The roles of message appeals and orientation on social media brand communication effectiveness: An evidence from Indonesia. Asia Pacific Journal of Marketing and Logistics, 30 (4), 1135-1158. https:/ /doi.org/10.1108/APJML-10-2017-0267

[41]. Laroche, M., Habibi, M.R, Marie-Odile, R., and Sankaranarayanan, R. (2012). The effects of social media based brand communities on brand community markers, value creation practices, brand trust and brand loyalty. Computers in Human Behavior, 28, 1755-1767. http://dx.doi.org/10.1016/j.chb.2012.04.016.

[42]. Lee, Min-Young, Kim, Y., Pelton, L., Knight, D., and Forney, J. (2008). Factors affecting Mexican college students' purchase intention toward a US apparel brand. Journal of Fashion Marketing and Management: An International Journal, 12 (3), 294-307. https://doi.org/10.1108/13612020810889263.

[43]. Li C. and Chang C. (2016). "The influence of trust and perceived playfulness on the relationship commitment of hospitality online social network-moderating effects of gender", International Journal of Contemporary Hospitality Management, Vol. 28, No. 5, pp. 924-944. 10.1108/IJCHM-05-2014-0227

[44]. Lichtenstein, D.R., Netemeyer, R.G., and Burton, S. (1990). Distinguishing coupon proneness from value consciousness: an acquisition transaction utility theory perspective. Journal of Marketing, 54 (3), 54-67.

[45]. Lin X., Featherman M. and Sarker S. (2017). "Understanding factors affecting users' social networking site continuance: A gender difference perspective", Information and Management, Vol. 54, pp. 383395. https:// doi.org/10.1016/j.im.2016.09.004

[46]. Liu Matthew Tingchi, Ip Kin Anthony Wong, Ting-Hsiang Tseng, Angela Wen-Yu Chang, Ian Phau, (2017). Applying consumer based brand equity in luxury hotel branding, Journal of Business Research, 81, 192-202. https://doi.org/10.1016/j.jbusres.2017.06.014

[47]. Ma E., Qu H. and Eliwa R.A. (2014). "Customer Loyalty With Fine Dining: The Moderating Role of Gender", Journal of Hospitality Marketing and Management, Vol. 23, pp. 513-535. https:/ / doi.org/10.1080/19368623.2013.835250

[48]. Manara, C., and Roquilly, C. (2011). The Risk of Brand Equity Erosion in the Social Media: the Efficacy and Limitations of Legal Instruments. Recherche et Applications en Marketing, 26 (3), 93-114.

[49]. Martín-Consuegra D., Díaza E., Gómez M. and Molina A. (2019). Examining consumer luxury brandrelated behavior intentions in a social media context: The moderating role of hedonic and utilitarian motivations. Physiology and Behavior. 200, 104-11. https:// doi.org/10.1016/j.physbeh.2018.03.028

[50]. Memery J., Angell R., Megicks P. and Lindgreen A. (2015). "Unpicking motives to purchase locallyproduced food: analysis of direct and moderation effects", European Journal of Marketing, Vol. 49, No. 7/8, pp. 1207-1233. 10.1108/EJM-02-2014-0075

[51]. Mukherjee, A., Satija, D., Goyal, T.M., Mantrala, M.K., and Zou, S. (2012). Are Indian consumers brand conscious? Insights for global retailers. Asia Pacific Journal of Marketing and Logistics, 24 (3), 482-499. https://doi.org/10.1108/13555851211237920.

[52]. Neuman W.L. (2014). Social Research Methods: Qualitative and Quantitative Approaches, Seventh Edition, Pearson Education Limited, USA

[53]. Ngai J. and Cho E. (2012). "The young luxury consumers in China", Young Consumers, Vol. 13 Issue: 3 , pp. 255-266, doi.org/10.1108/17473611211261656

[54]. Oliver R.L. (1997). Satisfaction: A Behavioral Perspective on the Consumer. McGraw-Hill, New York. 
[55]. Osei-Frimpong K. (2019). "Understanding consumer motivations in online social brand engagement participation: Implications for retailers", International Journal of Retail and Distribution Management, Vol. 47, No. 5, pp. 511-529. 10.1108/IJRDM-08-2018-0151

[56]. Park, H., and Kim, Y. (2014). The role of social network websites in the consumer-brand relationship, Journal of Retailing and Consumer Service. 21, 460-467. http:/ /dx.doi.org/10.1016/j.jretconser.2014.03.011.

[57]. Pérez A. and Rodríguez del Bosque I. (2015). "How customers construct corporate social responsibility images: Testing the moderating role of demographic characteristics", BRQ Business Research Quarterly, Vol. 18, pp. 127---141. https://doi.org/10.1016/j.brq.2014.04.003

[58]. Peruta, A., Ryan, W. and Engelsman, R. (2013). Social Media Branding Strategies for Higher Education: Comparing Facebook Pages and Web Sites. The International Journal of Technology, Knowledge and Society, 9.

[59]. Pillai, K.G. and Kumar, V. (2012). Differential Effects of Value Consciousness and Coupon Proneness on Consumers' Persuasion Knowledge of Pricing Tactics. Journal of Retailing, 88 (1), 20-33. doi:10.1016/j.jretai.2011.03.002.

[60]. Preacher K.J. and Hayes A.F. (2004). SPSS and SAS procedures for estimating indirect effects in simple mediation models. Behavior Research Methods, Instruments, and Computers, 36 (4), 717-731.

[61]. Rahman Z, Moghavvemmi S., Suberamanaian K., Zanuddin H. and Nasir H.N. (2018). "Mediating impact of fan-page engagement on social media connectedness and followers purchase intention", Online Information Review, Vol. 42, No. 7, pp. 1082-1105. https://doi.org/10.1108/OIR-05-2017-0150

[62]. Rambocas M., Kirpalani V.M. and Simms E. (2018). "Brand equity and customer behavioral intentions: a mediated moderated model", International Journal of Bank Marketing, Vol. 36, No. 1, pp. 19-40. 10.1108/IJBM-09-2016-0139

[63]. Rohm, A., Kaltcheva, V.D., and Milne, G.R. (2013). A mixed-method approach to examining brandconsumer interactions driven by social media. Journal of Research in Interactive Marketing, 7 (4), 295 311. http://dx.doi.org/10.1108/JRIM-01-2013-0009.

[64]. Rubio, N., Villaseñor, N., and Oubiña, J. (2014). Value and store brand identification in food products, British Food Journal, 116 (6), 965-983. https:/ / doi.org/10.1108/BFJ-01-2013-0028.

[65]. Shang, S.C., Wu, Y., and Sie, Y. (2016). Generating consumer resonance for purchase intention on social network sites. Computers in Human Behavior, 69, 18-28. http://dx.doi.org/10.1016/j.chb.2016.12.014.

[66]. Sharda N. and Bhat A.K. (2018). Austerity to materialism and brand consciousness: luxury consumption in India. Journal of Fashion Marketing and Management: An International Journal, 22 (2), 223-239. https://doi.org/10.1108/JFMM-03-2017-0025

[67]. Soh, C.Q.Y., Rezaei, S., and Gu, M. (2017). A structural model of the antecedents and consequences of Generation Y luxury fashion goods purchase decisions. Young Consumers, 18 (2), 180-204. https://doi.org/10.1108/YC-12-2016-00654.

[68]. Tiruwa A., Yadav R. and Suri P.K. (2018). "Moderating effects of age, income and internet usage on Online Brand Community (OBC)-induced purchase intention", Journal of Advances in Management Research, Vol. 15, No. 3, pp. 367-392. 10.1108/JAMR-04-2017-0043

[69]. Tolbert S.L., Kohli C. and Suri R. (2014). "Who pays the price for loyalty? The role of selfconsciousness", Journal of Product and Brand Management, 23/4/5, pp. 362-371. 10.1108/JPBM-082013-0375

[70]. Tong, X., Hawley, J.M. (2009). Creating brand equity in the Chinese clothing market: The effect of selected marketing activities on brand equity dimensions. Journal of Fashion Marketing and Management: An International Journal, 13 (4), 566-581.

[71]. Tsimonis, G., and Dimitriadis, S. (2014). Brand strategies in social media. Marketing Intelligence and Planning, 32 (3), 328 - 344. http:/ / dx.doi.org/10.1108/MIP-04-2013-0056.

[72]. Vendemia, M.A. (2017). When do consumers buy the company? Perceptions of interactivity in company-consumer interactions on social networking sites. Computers in Human Behavior, 71, 99-109. http://dx.doi.org/10.1016/j.chb.2017.01.046.

[73]. Vernuccio, M. (2014). Communicating Corporate Brands Through Social Media: An Exploratory Study, International Journal of Business Communication, 51 (3), 211 -233. 10.1177/2329488414525400.

[74]. Walsh G., Evanschitzky H. and Wunderlich M. (2008). "Identification and analysis of moderator variables, Investigating the customer satisfaction-loyalty link", European Journal of Marketing, Vol. 42, No. 9/10, pp. 977-1004. 10.1108/JPBM-07-2016-1267

[75]. Walsh G., Schaarschmidt M. and Ivens S. (2017). "Effects of customer-based corporate reputation on perceived risk and relational outcomes: empirical evidence from gender moderation in fashion retailing", Journal of Product and Brand Management, 26/3, pp. 227-238. 10.1108/JPBM-07-2016-1267 
[76]. Weisheng Chiu and Ho Keat Leng, (2016). "Consumers' intention to purchase counterfeit sporting goods in Singapore and Taiwan", Asia Pacific Journal of Marketing and Logistics, Vol. 28 Issue: 1, pp.23-36, https://doi.org/10.1108/APJML-02-2015-0031

[77]. Yadav M. and Rahman Z. (2018). "The influence of social media marketing activities on customer loyalty: A study of e-commerce industry", Benchmarking: An International Journal, Vol. 25, No. 9, pp. 3882-3905. 10.1108/BIJ-05-2017-0092

[78]. Yazdanparast, A., Joseph, M., and Muniz, F. (2016). Consumer based brand equity in the 21st century: an examination of the role of social media marketing. Young Consumers, 17 (3), 243 - 255. http://dx.doi.org/10.1108/YC-03-2016-00590.

[79]. Ye, L., Bose, M., and Pelton, L. (2012). Dispelling the collective myth of Chinese consumers: a new generation of brand-conscious individualists. Journal of Consumer Marketing, 29 (3), 190-201. https://doi.org/10.1108/07363761211221729.

[80]. Yilmaz, V. and Varol, S. (2015). Structural Equation Modeling With Software: Amos, Eqs, Lisrel. Dumlupinar University Journal of Social Sciences, 44, 28-44.

[81]. Yim, Y.M., Sauer, P.L., Williams, J., Lee, S., and Macrury, I. (2014). Drivers of attitudes toward luxury brands: A cross-national investigation into the roles of interpersonal influence and brand consciousness. International Marketing Review, 31 (4), 363-389. https://doi.org/10.1108/IMR-04-20110121.

[82]. Yoo, B., and Donthu, N. (2001). Developing and validating a multidimensional consumer-based brand equity scale. Journal of Business Research, 52, 1-14.

[83]. Zheng, X., Cheung, C.M.K., Lee, M.K.O., and Liang, L. (2015). Building brand loyalty through user engagement in online brand communities in social networking sites. Information Technology and People, 28 (1), 90 - 106. http:/ / dx.doi.org/10.1108/ITP-08-2013-0144 